\title{
AmpC beta-lactamase enzymes are ubiquitous in catfish (Clarias gariepinus) cultured in the Nigerian catfish grow-out pond systems
}

\author{
Faith I. AKINNIBOSUN ${ }^{1}$ and Odaro S. IMADE ${ }^{* 2}$ \\ ${ }^{1}$ Department of Microbiology, Faculty of Life Sciences, University of Benin, PMB 1154, Benin City, Edo State, \\ Nigeria \\ ${ }^{2}$ Department of Biological Sciences, College of Natural and Applied Sciences, Igbinedion University, Okada, Edo \\ State, Nigeria
}

\begin{abstract}
This research was performed to ascertain the ubiquity of bacterial pathogens which hyper-produced AmpC $\beta$ lactamase enzymes in adult catfish cultured in the Nigerian catfish grow-out pond systems. Phenotypic and molecular methods were used to isolate and identify bacterial pathogens that hyper-produced AmpC $\beta$-lactamase enzymes. The AmpC $\beta$-lactamase enzymes produced by the bacterial pathogens were subsequently characterized by BLASTX and RPSBLAST bioinformatics software as well as with the Cn3D molecular modelling software. Findings from the present study indicated that pathogenic bacterial strains which hyper-produced the AmpC $\beta$-lactamase enzymes were isolated from 49 catfish samples out of the 54 catfish samples which were examined. The pathogenic bacterial strains were mainly identified as Citrobacter freundii MGH 150, Enterobacter cloacae NG 14, and Enterobacter cloacae subspecies dissolvens HKE 15. The AmpC $\beta$-lactamase enzymes produced by the bacterial pathogens were also respectively identified as cephalosporinase hydrolyzing class C CMY-LAT-MOX-ACT-MIR-FOX, CMY2/MIR/ACT/EC family class $\mathrm{C}$ beta-lactamase, and CMY2/MIR/ACT/EC family class C beta-lactamase. The presence of AmpC enzymes that are hyper-produced by bacterial pathogens which were isolated from almost all the catfish examined calls for urgent monitoring/surveillance of the Nigerian catfish ponds by the relevant regulatory agencies.
\end{abstract}

Keywords: cephalosporinase hydrolyzing class C CMY-LAT-MOX-ACT-MIR-FOX; CMY2/MIR/ACT/EC family class $\mathrm{C}$ beta-lactamase; Citrobacter freundii; Enterobacter cloacae.

\section{Introduction}

AmpC $\beta$-lactamases are often referred to as cephalosporinases that are not often inhibited by betalactamase inhibitors [1 - 3]. These enzymes are found to mainly occur in most of the Enterobacteriaceae and a few other organisms [4]. The genes encoding AmpC $\beta$ lactamase enzymes are often located on the bacterial chromosomes $[3,5,6]$.

Several studies [4, 5, 7] have also shown that in organisms such as Escherichia coli, Salmonella species, and Klebsiella species, the genes encoding AmpC $\beta$ lactamase enzymes are located on the bacterial plasmids. In aquaculture systems, well-established relationships exist between the hyper-production of AmpC $\beta$ lactamase enzymes and the abuse/misuse of antibiotics which often results in the emergence of multidrugresistant pathogens that may cause human illnesses and other health consequences.

Unlike in Europe and the United States [8 - 10], there is a high likelihood that catfish ponds in Nigeria [10 - 12] are reservoirs of bacterial pathogens which hyperproduce AmpC $\beta$-lactamase enzymes because control of aquaculture operations in catfish ponds is not enforced. Hence, this research was performed to ascertain the ubiquity of bacterial pathogens which hyper-produced AmpC $\beta$-lactamase enzymes in adult catfish grown in the Nigerian catfish grow-out ponds.

\section{Experimental}

\subsection{Study area}

Edo (Latitude: $6.5438^{\circ} \mathrm{N}, 5.8987^{\circ} \mathrm{E}$ ), Ondo (Latitude: $6.8959^{\circ} \mathrm{N}, 4.8936^{\circ} \mathrm{E}$ ), and Anambra (Latitude: $6.2758^{\circ}$ $\mathrm{N}, 7.0068^{\circ} \mathrm{E}$ ) states of Nigeria were the sampling sites which were selected for this study.

In Edo state, catfish samples were collected from catfish ponds situated at Ofunmwengbe and Iguoriakhi. Catfish samples were collected from catfish ponds situated at Amansea and Ekwulobia communities in Awka North and Aguata local government areas of Anambra state. Catfish samples were also collected from catfish ponds situated at Farm-Settlement and Ago Taiye communities in Okitikpupa and Irele local government areas of Ondo state.

Overall, 54 fresh fattened catfish samples were collected from the catfish grow-out ponds.

\subsection{Isolation of enteric bacteria which hyper-produced AmpC beta-lactamase enzymes \\ Enteric bacterial colonies were isolated from the catfish samples by a streak-plating technique in which $100 \mu \mathrm{l}$ of a series of diluted catfish sample $\left(10^{-1}-10^{-5}\right.$ dilutions $)$ were inoculated on to sterile crystal violet red bile agar plates that contained ceftriaxone antibiotic [13]. Incubation of the agar plates was subsequently done at 37 ${ }^{\circ} \mathrm{C}$ for 18 - 20 hours, after which bacterial isolates on the agar plates which hyper-produced AmpC beta-lactamase}

\footnotetext{
* Corresponding author. E-mail address: imade.stanley@gmail.com (Odaro S. Imade)
} 
enzymes were detected with phenotypic and molecular methods [13 - 15].

\subsection{Genus-level identification of enteric bacterial isolates which hyper-produced AmpC beta-lactamase enzymes}

The phenotypic techniques employed for the genus-level identification was performed with standard methods [13, 16]. Hemolysis test (hemolysin expression) was performed with nutrient agar plates containing $5 \%$ human erythrocytes on which the bacteria isolates were grown under aerobic conditions [17]. Hemolysin virulence trait was confirmed with the polymerase chain reaction technique (PCR) [18]. AmpC beta-lactamaseproducing bacterial isolates that exhibited $\beta$-hemolytic traits were confirmed as AmpC beta-lactamaseproducing bacterial pathogens.

\subsection{Species-level identification of enteric bacterial pathogens which hyper-produced AmpC beta- lactamase enzymes}

PCR and DNA sequencing were performed on the ultrapure DNA templates of the pathogenic bacterial isolates as previously described [13, 19]. Taxonomic classification of the pathogenic bacterial isolates was confirmed by a search of the $16 \mathrm{~S}$ rRNA database of bacteria and archaea in the GenBank. The reference sequence having the highest score in terms of sequence similarity and sequence identity was considered the best match for a given query bacterial isolate.

\subsection{Characterization of AmpC beta-lactamase enzymes produced by the enteric bacterial pathogens}

The three-dimensional (3D) domains of the enzymes was annotated with the $\mathrm{Cn} 3 \mathrm{D}$ version 4.3 modelling software in order to understand the structure/function relationships associated with the AmpC beta-lactamase enzymes.

\subsection{Data analysis}

NCSS data analysis software was used to statistically describe the prevalence datasets.

\section{Results and discussion}

\subsection{Prevalence of AmpC beta-lactamase enzymes in the aqua-cultured catfish}

Table 1 represents the prevalence of AmpC betalactamase enzymes in fattened catfish samples collected from catfish ponds in Nigeria. High prevalence of bacterial resistance to phenotypic markers (amoxicillin plus clavulanic acid antibiotics combination and ceftazidime antibiotic) of bacteria which hyper-produced AmpC $\beta$-lactamase enzymes was seen in the catfish samples. Of the 324 ceftriaxone-resistant bacterial isolates examined, 282 isolates were resistant to amoxicillin plus clavulanic acid antibiotics combination; while 263 isolates were resistant to ceftazidime antibiotic. Sequence analysis of the PCR products obtained from 282 presumptive bacterial isolates indicated that 237 of the presumptive isolates hyperproduced AmpC $\beta$-lactamase enzymes. Bacterial pathogens producing these AmpC $\beta$-lactamase enzymes were isolated from 49 catfish samples out of the 54 catfish samples which were examined.

\subsection{Identification of enteric bacterial pathogens which hyper-produced AmpC beta-lactamase enzymes \\ The enteric bacterial pathogens were identified as Enterobacter cloacae and Citrobacter freundii (Table 2). GenBank accession numbers for some deposited novel AmpC $\beta$-lactamase-producing pathogenic strains were MH071286, MH027595, and MH027596. Enterococcus faecalis and Escherichia coli (Table 2) were reported as non-pathogenic species because they exhibited no hemolytic trait.}

Table 1. Prevalence of AmpC beta-lactamase enzymes

\begin{tabular}{|c|c|c|c|c|c|c|c|c|c|c|c|}
\hline \multicolumn{6}{|c|}{$\begin{array}{l}\text { Presumptive prevalence of AmpC } \beta \text {-lactamase-producing bacterial } \\
\text { isolates with their antibiotics resistance profile } \\
\qquad \mathrm{N}=324\end{array}$} & \multirow{2}{*}{\multicolumn{3}{|c|}{$\begin{array}{l}\text { Confirmed prevalence of AmpC } \\
\beta \text {-lactamase enzymes in the } \\
\text { presumptive bacterial isolates } \\
\qquad \mathrm{n}=282\end{array}$}} & \multirow{2}{*}{\multicolumn{3}{|c|}{$\begin{array}{l}\text { Prevalence of catfish } \\
\text { contaminated with the } \\
\text { AmpC } \beta \text {-lactamase enzymes } \\
\qquad \mathrm{C}=54\end{array}$}} \\
\hline \multicolumn{3}{|c|}{ Amoxycillin + Clavulanic acid } & \multicolumn{3}{|c|}{ Ceftazidime } & & & & & & \\
\hline $\begin{array}{l}\text { Mean } \\
\times 100 \%\end{array}$ & $\begin{array}{l}\text { S. error } \\
\times 100 \%\end{array}$ & $\begin{array}{l}95 \% \mathrm{CI} \\
\times 100 \% \\
\end{array}$ & $\begin{array}{l}\text { Mean } \\
\times 100 \% \\
\end{array}$ & $\begin{array}{l}\text { S. error } \\
\times 100 \% \\
\end{array}$ & $\begin{array}{l}95 \% \mathrm{CI} \\
\times 100 \%\end{array}$ & $\begin{array}{l}\text { Mean } \\
\times 100 \% \\
\end{array}$ & $\begin{array}{l}\text { S. error } \\
\times 100 \%\end{array}$ & $\begin{array}{l}95 \% \mathrm{CI} \\
\times 100 \% \\
\end{array}$ & $\begin{array}{l}\text { Mean } \\
\times 100 \% \\
\end{array}$ & $\begin{array}{l}\text { S. error } \\
\times 100 \%\end{array}$ & $\begin{array}{l}95 \% \mathrm{CI} \\
\times 100 \% \\
\end{array}$ \\
\hline 0.87 & 0.02 & $0.83-0.91$ & 0.81 & 0.02 & $0.77-0.85$ & 0.84 & 0.02 & $0.80-0.88$ & 0.91 & 0.04 & $0.83-0.99$ \\
\hline
\end{tabular}

$\mathrm{N}$ : the total number of ceftriaxone-resistant bacterial isolates examined; $\mathrm{n}$ : number of presumptive AmpC $\beta$-lactamase-producing bacterial isolates examined; $\mathrm{C}$ : the total number of catfishes analyzed.

Table 2. Phenotypic and molecular characterization of AmpC $\beta$-lactamase-producing isolates obtained from catfish pond systems

\begin{tabular}{|c|c|c|c|c|c|c|c|c|c|c|c|c|}
\hline \multirow{2}{*}{$\begin{array}{l}\text { Main } \\
\text { isolates }\end{array}$} & \multicolumn{3}{|c|}{ Morphological characterizations } & \multicolumn{6}{|c|}{ Biochemicalcharacterizations } & \multicolumn{2}{|c|}{ 16SrRNA sequence homology } & \multirow[t]{2}{*}{ Identified Organisms } \\
\hline & $\begin{array}{l}\text { Colonial appearance } \\
\text { on CCVRBA plates }\end{array}$ & Gram staining & HM & $\mathrm{CA}$ & ox & CI & IN & MR & VP & 16S Similarity & 16S Identity & \\
\hline 1. & Pink colonies & Gram positive cocci & $\gamma$ & - & - & + & - & - & + & $95-99 \%$ & $93-97 \%$ & Enterococeus faecal is \\
\hline 2. & Pink colonies & Gramnegative rods & $\beta$ & + & - & + & - & - & - & $96-98 \%$ & $90-96 \%$ & Enterobacter cloacae \\
\hline 3. & Pink colonies & Gramnegative rods & $\beta$ & + & - & + & - & - & - & $92-98 \%$ & $81-88 \%$ & $\begin{array}{l}\text { Enterobacter cloacae subsp } \\
\text { dissolvens }\end{array}$ \\
\hline 4. & Pink colonies & Gramnegative rods & $\gamma$ & + & - & - & + & + & - & $94-99 \%$ & $92-94 \%$ & Escherichiacoli \\
\hline 5. & Pink colonies & Gramnegative rods & $\beta$ & + & - & + & - & + & - & $91-93 \%$ & $85-89 \%$ & Citrobacter freundii \\
\hline
\end{tabular}

CCVRBA: crystal violet red bile agar containing ceftriaxone antibiotic; HM: hemolysis test; CA: catalase test; OX: oxidase test; CI: citrate test; IN: indole test; MR: methyl red test; VP: Voges Proskauer test; $\beta$ : beta hemolysis; $\gamma$ : gamma hemolysis. 


\subsection{Characterization of AmpC beta-lactamase enzymes} As shown in Figure 1, BLASTX conducted on the translated nucleotide sequence of the query protein genes in the pathogenic bacterial isolates obtained from the catfish revealed that they produced AmpC $\beta$-lactamase enzymes that could inhibit the antibacterial activity of cephamycins, latamoxef, moxalactam, and cefoxitin.

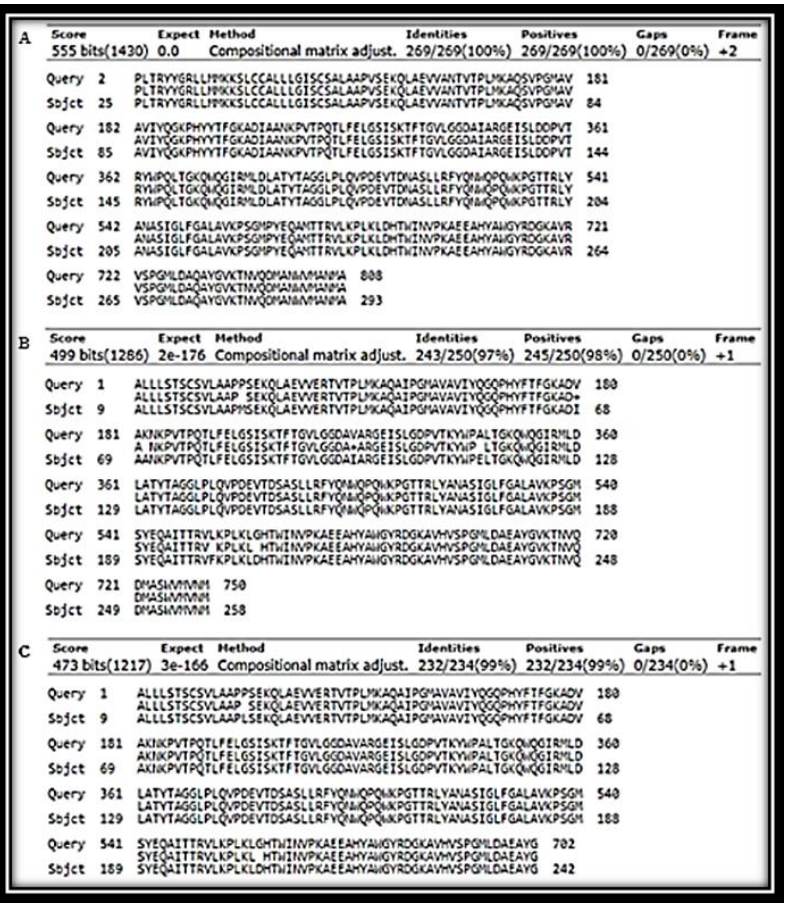

Figure 1. BLASTX pair-wise sequence alignments between the NCBI reference (sbjct) translated nucleotide sequences of an uncultured bacterium (A), Enterobacter sp. MGH 24 (B),

Enterobacter multispecies (C) and those of the query translated nucleotide sequences obtained from Citrobacter freundii MGH 150 (A), Enterobacter cloacae NG 14 (B), Enterobacter cloacae subspecies dissolvens HKE 15 (C). Ambler class $\mathrm{C}$ beta-lactamase enzymes were identified as cephlosporinase hydrolyzing class C CMY-LAT-MOX-ACTMIR-FOX (A), CMY2/MIR/ACT/EC family class C betalactamase (B), and CMY2/MIR/ACT/EC family class $\mathrm{C}$ betalactamase (C).

The deposited AmpC beta-lactamase enzymes produced by the isolated pathogenic bacterial strains and their respective translated nucleotide sequences have also been assigned the following GenBank accession numbers: AXH01352, AXH01353, AXH01354, MH110561, MH110562, and MH110563.

The 3D domain structure of the AmpC $\beta$-lactamase enzymes produced by the bacterial pathogens is shown in Figure 2.

Findings from this research indicated that bacterial pathogens isolated from the fattened catfish samples hyper-produced AmpC $\beta$-lactamase enzymes. The hyperproduction of AmpC $\beta$-lactamase enzymes commonly occur under antibiotic treatment $[6,20]$, thus, confirming that antibiotics may be grossly abused during aquaculture operations in the Nigerian catfish ponds. Since there were no published data from other Nigerian authors to compare findings of the present study, this may be the first empirical report in Nigeria of induced AmpC beta- lactamase enzymes in the fattened catfish collected from Nigerian catfish ponds.

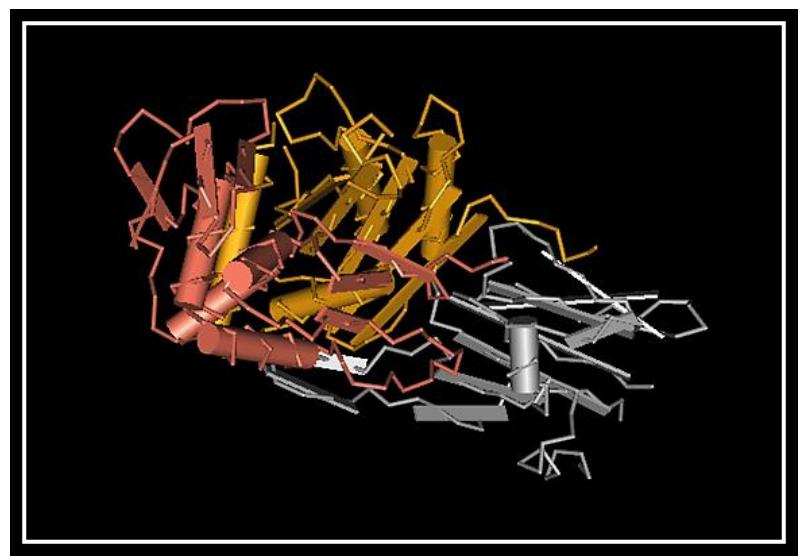

Figure 2. 3D structure of the AmpC beta-lactamase enzymes produced by the bacterial pathogens harbored in the Nigerian grow-out pond systems revealing the three domains which constitute the protein. Each 3D domain is shown in the same color. It was implemented with the $\mathrm{Cn} 3 \mathrm{D}$ modelling software.

Several studies $[11,12]$ have shown that antibiotics may be grossly abused during aquaculture operations in the Nigerian catfish ponds. There were also no published data implicating aquaculture-produce from European countries as reservoirs of AmpC $\beta$-lactamase-producing bacteria. The findings of Boss et al. [10] who reported that no multidrug-resistant bacteria were found in aquaculture-produce collected from European aquaculture systems $[10,13]$ is an indication that AmpC $\beta$-lactamase enzymes may probably not be present in the aquaculture-produce since antibiotics were rarely abused in the European aquaculture systems [8].

\section{Conclusion}

The study revealed that AmpC $\beta$-lactamase-producing bacterial pathogens were harbored in catfish cultured in the Nigerian grow-out ponds. These bacterial pathogens could be directly transmitted to humans or indirectly transmitted via a horizontal transfer of the inducible AmpC $\beta$-lactamase genes to clinically relevant pathogens which may ultimately cause illnesses that are very difficult to treat. Hence, relevant regulatory agencies in Nigeria should commence intensive surveillance of catfish ponds to ameliorate the burden of multidrugresistant bacterial pathogens.

\section{Conflict of interest}

No conflict of interest declared.

\section{References}

[1]. R.P. Ambler, The structure of beta-lactamases, Philosophical Transactions of the Royal Society of Biological Sciences 289 (1980) 321 - 331.

[2]. K. Bush, G.A. Jacoby, A. A. Medeiros, A functional classification scheme for beta-lactamases and its correlation with molecular structure, Antimicrobial Agents and Chemotherapy 39 (1995) 1211 - 1233. 
[3]. N.D. Hanson, AmpC $\beta$-lactamases: what do we need to know for the future? Journal of Antimicrobial Chemotherapy 52 (2003) $2-4$.

[4]. G.A. Jacoby, AmpC $\beta$-lactamases, Clinical Microbiology Reviews 22 (2009) 161-182.

[5]. F.J. Pérez-Pérez, D.H. Hanson, Detection of plasmid-mediated AmpC $\beta$-lactamase genes in clinical isolates by using multiplex PCR, Journal of Clinical Microbiology 40 (2002) 2153 2162.

[6]. European Medicines Agency (EMA), Scientific advisory group on antimicrobials of the committee for medicinal products for veterinary use: reflection paper on the use of third and fourth generation cephalosporins in food producing animals in the European Union: development of resistance and impact on human and animal health, Journal of Veterinary and Pharmacological Therapy 32 (2009) $515-533$.

[7]. P.R. Mohamudha, B. N. Harish, S. C. Parija, Molecular description of plasmid-mediated AmpC $\beta$ - lactamases among nosocomial isolates of Escherichia coli and Klebsiella pneumoniae from six different hospitals in India, Indian Journal of Medical Research 135 (2012) $114-119$.

[8]. C. Cogliani, H. Goossens, C. Greko, Restricting antimicrobial use in food animals: lessons from Europe microbe, Microbiome 6 (2011) 274.

[9]. M.K. Chattopadhyay, Use of antibiotics as feed additives: a burning question, Frontiers in Microbiology 5 (2014) 334 - 337.

[10]. R. Boss, G. Overesch, A. Baumgartner, Antimicrobial resistance of Escherichia coli, Enterococci, Pseudomonas aeruginosa, and Staphylococcus aureus from raw fish and seafood imported into Switzerland, Journal of Food Protection 79 (2016) 1240 - 1246.

[11]. M.O. Efuntoye, K.B. Olurin, G.C. Jegede, Bacterial flora from healthy Clarias gariepinus and their antimicrobial resistance pattern, Advanced Journal of Food Science and Technology 4 (2012) 121 125.

[12]. F.O. Ekundayo, D.O. Diyaolu, E.A. Fasakin, Composition, distribution and antibiotic sensitivities of bacteria associated with cultured Clarias gariepinus (Burchell 1822), Malaysia Journal of Microbiology 10 (2014) 72 - 79.

[13]. O.S. Imade, F.I. Akinnibosun, The Nigerian catfish (Clarias gariepinus) pisciculture systems: reservoirs of multidrug-resistant bacteria, Journal of Applied Microbiology 125 (2018) 1552 - 1568.

[14]. T. Conceicao, N. Faria, L. Lito, J.M. Cristino, J.M. Salgado, A. Duarte, Diversity of chromosomal AmpC L-lactamases from Enterobacter cloacae isolates in a Portuguese hospital, FEMS Microbiology Letters 230 (2004) 197 - 202.

[15]. E. Sanger, S. Nicklen, A. Coulson, DNA sequencing with chain terminating inhibitors, Proceedings of the National Academy of Science 74 (1977) 5463 - 5467.

[16]. G.I. Barrow, R. K. A. Feltham, Cowan and Steel's Manual for the identification of Medical Bacteria ( $3^{\text {rd }}$ ed.), Cambridge University Press, United Kingdom, pp. 129 - 149 (2003).

[17]. K. Murase, T. Ooka, A. Iguchi, Y. Ogura, K. Nakayama, M.D. Asadulghani, Haemolysin E- and enterohaemolysin-derived haemolytic activity of O55/O157 strains and other Escherichia coli lineages, Microbiology 158 (2012) 746 -758.

[18]. S.P.K. Surendran, N. Thampuran, PCR-based detection of enterotoxigenic isolates of B. cereus from tropical seafood, Indian Journal of Medical Research 129 (2009) 316 - 320.

[19]. D.J. Lane, 16S/23S rRNA sequencing. In: Nucleic acid techniques in bacterial systematics E. Stackebrandt, M. Goodfellow (ed.). John Wiley and Sons, New York, USA, pp. 115 - 175 (1991).

[20]. A.O. Adeyemo, Fish diseases symptoms as observed by fish farmers in Ogbia and Yenagoa local government areas of Bayelsa State Nigeria, Journal of Agricultural and Veterinary Sciences 3 (2011) $13-16$.

Received: 1.02 .2019

Received in revised form: 13.03.2019

Accepted: 15.03.2019 